each profile by dipping the electrode into numerous water-filled cryoconite holes in a search for high conductivity signals of volcanic origin. The method was suggested by Claus Hammer, Geophysical Institute, University of Copenhagen. High conductivity signals were found at similar positions in the two profiles, but it is not yet clear whether these can be interpreted as reflecting a volcanic eruption.

Acknowledgements. Anker Weidick (GGU) collected ice samples at the margins of Jakobshavn Isbræ and Alangardliup sermia, Claus Kern-Hansen and Jens Valeur (Greenland Technical Organization) collected water samples from $S \varnothing 187$ and Sø 233, Mark Meier and Tad Pfeffer (INSTAAR, University of Colorado) helped collect ice samples, Hans Oerlemans (University of Utrecht) and Henrik Højmark Thomsen (GGU) helped with the conductivity measurements, and Henrik $\mathrm{H} ø$ mark Thomsen, Roger J. Braithwaite, Ole B. Olesen, and Carl Bøggild (GGU) helped with the logistic organization.

\section{References}

Reeh, N. \& Thomsen, H. H. 1986: Stable isotope studies on the Greenland ice-sheet margin. Rapp. Grønlands geol. Unders. 130, 108-114.

Reeh, N., Thomsen, H. H. \& Clausen, H. B. 1987a: The Greenland ice-sheet margin - a mine of ice for paleo-environmental studies. Palaeogeogr., Palaeoclimat., Palaeoecol. 58, 229-234.

Reeh, N., Hammer, C. U., Thomsen, H. H. \& Fisher, D. A. 1987b: Use of trace constituents to test flow models for ice sheets and ice caps. Publ. Assoc. int. hydrol. Scient. 170, 299-310.

Souchez, R. \& Jouzel, J. 1984: On the isotopic composition in $\delta \mathrm{D}$ and $\delta^{18} \mathrm{O}$ of water during freezing. J. Glaciol. 30(106), 369-372.

Thomsen, H. H. 1987: Continued glaciological work north-east of Jakobshavn, West Greenland. Rapp. Grønlands geol. Unders. 135, 84-87.

N. R., A. L., H. O. Alfred Wegener Institute for Polar and Marine Research, Postfach 120161, Columbusstrasse D-2850 Bremerhaven West Germany.

\title{
Glacier-climate studies 1987-1988 at Qamanârssûp sermia, West Greenland
}

\author{
Roger J. Braithwaite
}

As part of the GGU programme of hydropower investigations in West Greenland, glaciological and climatological measurements were made at the Qamanârssûp sermia field station for the seven summers 19801986. However, the station was deactivated at the end of the 1986 field season (Braithwaite, 1987) and only a reduced measurement programme was carried out in 1987-1988.

\section{Field work 1987-1988}

The automatic climate station at base camp was kept in operation and the glaciological programme was limited to what could be done on one-day visits by helicopter in May and in late August. In 1987 both visits had to be curtailed due to unforeseen problems with helicopters. This meant that not all stakes could be found in 1987 and that there was not enough time to redrill other stakes which therefore melted out. The glaciological programme in 1988 was reduced to maintaining the '751' stakes, near to the old base camp, and stake 15 high up on the ice sheet (fig. 1).

\section{Results 1987-1988}

The data for net ablation are given in Table 1 for seven stakes in 1986/87 and two stakes in 1987/88 compared with the 1979-1986 means at the same stakes. There was very high ablation in 1987 so that the ' 751 ' stakes melted out while the net ablation at the remaining seven stakes was higher than the 7-year mean by 0.2 to $1.3 \mathrm{~m}$ water. By contrast, net ablation in $1987 / 88$ at the two stakes are respectively 0.3 and $0.2 \mathrm{~m}$ water lower than the average.

Data for monthly mean temperatures from the automatic climate station are given in Table 2; data for August 1988 are still incomplete.

The high ablation in the summer of 1987 was obviously due to exceptionally high temperatures in both June and August 1987 although July 1987 was rather cool. Overall, the 1987 summer was the warmest on record although the net ablation was generally a little less than in 1985 which was the next warmest summer. However, ablation in 1985 was higher than could be expected from the high temperatures because the degree-day factor was also higher than normal (Braith- 
Fig. 1. Locations of stakes on Qamanârssûp sermia.

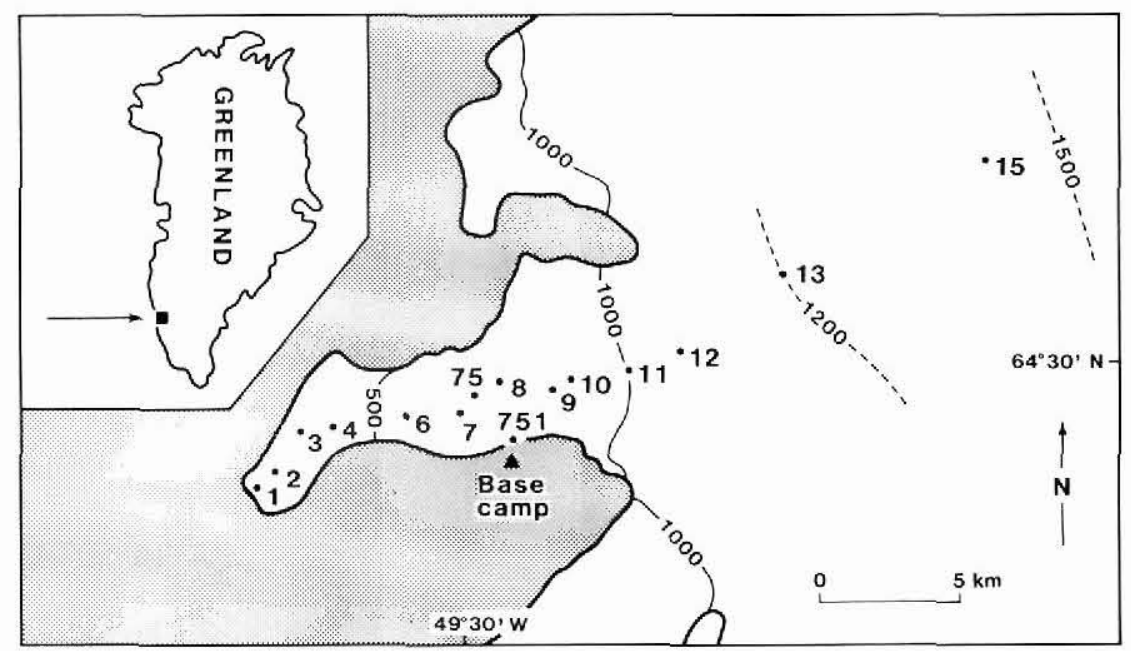

Table 1. Net ablation data 1987-1988 compared with mean values for 1979-1986, Qamanârssûp sermia

\begin{tabular}{rcccc}
\hline STAKE & $\begin{array}{c}\text { Elevation } \\
\text { m a.s.1. }\end{array}$ & Mean & $1986 / 87$ & $1987 / 88$ \\
\hline 6 & 580 & 3.93 & 4.7 & \\
7 & 680 & 3.40 & 4.7 & \\
75 & 760 & 4.14 & 4.9 & 4.2 \\
751 & 790 & 4.54 & & \\
9 & 910 & 2.40 & 2.8 & \\
10 & 930 & 1.79 & 2.9 & \\
13 & 1200 & 0.27 & 0.6 & \multirow{2}{*}{0.0} \\
15 & 1410 & 0.19 & 0.4 & 0.0 \\
\hline
\end{tabular}

Units are metres of water

waite, 1986a). The low ablation in 1988 appears to be due to exceptionally low temperatures in June, which probably offset high temperatures in July 1988.

\section{Research}

The main priority of the work has now shifted from collection of new data to analysis of the large amount of data already collected during 1980-1986. The main emphasis is on developing models which can be compared with those from other GGU stations and which will allow regional syntheses to be made.

Properties of sparse stake networks. Ablation in Greenland cannot be measured with such dense stake networks as those considered necessary in other areas, but sparse stake networks still give useful information on ablation time-variations (Braithwaite, 1986b). This is because ablation variations can be broken down into separate space and time variations where the latter consists of both ablation signal and noise. Braithwaite \& Olesen (in press 2) extend this concept and use interstake correlation to detect suspect data and reduce noise. For example, the noise standard deviation is reduced to only $\pm 0.28 \mathrm{~m}$ water equivalent compared with the ablation signal of $\pm 0.55 \mathrm{~m}$ water for eight centreline stakes in the period 1980-1986.

Ablation-temperature model. The simplest link between glaciers and climate is the correlation between ablation and air temperature demonstrated by Braithwaite \& Olesen (1985) using daily ablation data for five summers from the ' 751 ' stakes near to base camp. The model has now been updated with data for a further two summers (Braithwaite \& Olesen, in press 3 ). However, the ablation-temperature relation is probably modified by the

Table 2. Monthly mean temperature for base camp, Qamanârssûp sermia

\begin{tabular}{lcccc}
\hline & June & July & August & Summer \\
\hline 1980 & 4.7 & 6.6 & 5.5 & 5.6 \\
1981 & 5.2 & 7.5 & 3.9 & 5.5 \\
1982 & 4.9 & 6.0 & 4.3 & 5.1 \\
1983 & 3.3 & 5.2 & 1.8 & 3.4 \\
1984 & 4.4 & 7.5 & 4.7 & 5.5 \\
1985 & 5.6 & 6.4 & 6.2 & 6.1 \\
1986 & 2.6 & 7.0 & 6.0 & 5.2 \\
1987 & 6.9 & 5.6 & 6.8 & 6.4 \\
1988 & 2.0 & 7.3 & $\mathrm{n} / \mathrm{a}$ & \\
\hline
\end{tabular}

Units are ${ }^{\circ} \mathrm{C}$ 
effect of snow accumulation, which is shown by Braithwaite \& Olesen (in press 1 ) to reduce ice ablation on Nordbogletscher; this will be investigated for Qamanârssûp sermia.

Energy-balance model. The ablation-temperature correlation cannot explain all ablation variations, and an energy-balance model is now being tested. The model estimates ablation as the sum of turbulent and radiative fluxes. The turbulent fluxes are calculated from air temperature, wind speed and vapour pressure (Ambach, 1986), shortwave radiation is estimated from measured global radiation, and longwave radiation is calculated from air temperature and cloud amount (Ohmura, 1981). Despite the relative simplicity of the model it calculates ablation with reasonable accuracy. A full report is in preparation.

\section{Applications}

The improved ablation-temperature model using seven summers of data from Qamanârssûp sermia (see above) has been used to simulate annual runoff for planning hydropower at Ilulissat/Jakobshavn (Braithwaite \& Thomsen, in press). The results generally agree with the earlier simulation by Braithwaite \& Thomsen (1984) but provide a safer basis for planning. However, a better ablation model will be needed for short-term forecasting of runoff if the hydropower plant is ever built. The new energy-balance model (see above) could be used for this purpose but should also be tested with field data from the Ilulissat area.

The ablation-temperature and energy-balance models can also be used for predicting ablation changes caused by the greenhouse effect. For example, trial calculations using the energy-balance model show that ablation at Qamanârssûp sermia changes by more than half a metre of water for every degree change in summer temperature. Extrapolation of this result to the whole Greenland ice sheet (which may be questionable) suggests a possible world sea level rise of about $24 \mathrm{~cm}$ per century for a $5^{\circ} \mathrm{C}$ change in summer temperature. This should not be taken too seriously as a final result, but indicates the need for further work. For example, the energy-balance model must be applied to various sites to study inter-site variations.
Acknowledgements. Henrik Højmark Thomsen (GGU) helped with all data collection in 1987 and in May 1988. Dr J. Oerlemans, University of Utrecht, accompanied the author on the August 1988 visit to Qamanârssûp sermia. The automatic climate station at Qamanârssûp sermia is operated on behalf of GGU by the Section for Hydro-technical Investigations, Greenland Technical Organization.

\section{References}

Ambach, W. 1986: Nomographs for determination of meltwater from snow and ice surfaces. Ber. nat.-med. Verein Innsbruck 73, 181-189.

Braithwaite, R. J. 1986a: Exceptionally high ablation in 1985 at Qamanârssûp sermia, West Greenland. Rapp. Grønlands geol. Unders. 130, 126-129.

Braithwaite, R. J. 1986b: Assessment of mass-balance variations within a sparse stake network, Qamanârssûp sermia, West Greenland. J. Glaciol. 32, 50-53.

Braithwaite, R. J. 1987: The last full summer of glacier-climate investigations at Qamanârssûp sermia, West Greenland. Rapp. Grønlands geol. Unders. 135, 95-99.

Braithwaite, R. J. \& Olesen, O. B. 1985: Ice ablation in West Greenland in relation to air temperature and global radiation. Z. Gletscherkd. Glazialgeol. 20, 155-168.

Braithwaite, R. J. \& Olesen, O. B. in press 1: Winter accumulation reduces summer ablation on Nordbogletscher, South Greenland. Z. Gletscherkd. Glazialgeol. 24.

Braithwaite, R. J. \& Olesen, O. B. in press 2: Detection of ablation signal by inter-stake correlations of annual ablation data, Qamanârssûp sermia, West Greenland. J. Glaciol.

Braithwaite, R. J. \& Olesen, O. B. in press 3: Calculation of glacier ablation from air temperature, West Greenland. Conference on glacier fluctuations and climatic change, Amsterdam, 1-5 June 1987.

Braithwaite, R. J. \& Thomsen, H. H. 1984: Runoff conditions at Paakitsup Akuliarusersua, Jakobshavn, estimated by modelling. Grønlands geol. Unders. Gletscher-hydrol. Meddr 84/3, $22 \mathrm{pp}$.

Braithwaite, R. J. \& Thomsen, H. H. in press: Simulation of runoff from the Greenland ice sheet for planning hydroelectric power, Ilulissat/Jakobshavn, West Greenland. Annals Glaciol.

Ohmura, A. 1981: Climate and energy balance on arctic tundra, Axel Heiberg Island, Canadian Arctic Archipelago. Zürcher Geogr. Schrift. 3, 448 pp.

R. J. B., Grønlands Geologiske Undersøgelse, Oster Voldgade 10, $D K-1350$ København $K$, Danmark. 